\title{
L'outre ou la jarre? Le beurre et les barattes dans l'Orient ancien
}

\section{Philippe Gouin}

\section{(2) OpenEdition \\ 1 Journals}

Édition électronique

URL : https://journals.openedition.org/tc/468

DOI : $10.4000 /$ tc.468

ISSN : 1952-420X

Éditeur

Éditions de l'EHESS

\section{Édition imprimée}

Date de publication : 1 novembre 1997

ISSN : 0248-6016

\section{Référence électronique}

Philippe Gouin, «L'outre ou la jarre ? Le beurre et les barattes dans I'Orient ancien », Techniques \& Culture [En ligne], 28 | 1997, mis en ligne le 28 octobre 2005, consulté le 29 septembre 2022. URL http://journals.openedition.org/tc/468; DOI : https://doi.org/10.4000/tc.468

Ce document a été généré automatiquement le 29 septembre 2022.

Tous droits réservés 
L'outre ou la jarre? Le beurre et les barattes dans l'Orient ancien

Philippe Gouin 